\title{
EDVI ILLÉS ALADÁR, A MAGYAR IPARFEJLESZTÉS KIEMELKEDŐ SZEMÉLYISÉGE
}

\section{ILLÉS ALADÁR EDVI, PERSONALITY OF THE HUNGARIAN INDUSTRY INNOVATION}

\author{
Gáti József ${ }^{1}$, Talpas János ${ }^{2}$ \\ ${ }^{I}$ Óbudai Egyetem, 1034, Budapest, Bécsi út 96/b; Telefon: 666-5604 Fax: 666- \\ 5621,gati@uni-obuda.hu \\ ${ }^{2}$ Babeș-Bolyai Tudományegyetem, Földrajz Kar, 400006 Kolozsvár/Cluj-Napoca, \\ Str. Clinicilor Nr.5-7., talpasjanos@gmail.com
}

\begin{abstract}
The 19th century gave to Hungarian Economy a large number of prominent professionals. An outstanding talent of them was Illés Aladár Edvi, a mechanical engineer. Teacher of the Hungarian Royal Public Higher Industrial School (predecessor of the Óbuda University), open-minded and famous for his excellent theoretical skills, he wrote his name into the history books not only as a teacher but as industry developer and innovator too, between the years $1882-1920$.
\end{abstract}

Keywords: Hungarian Royal Public Higher Industrial School, industry politic, teacher, publicist

\section{Összefoglalás}

A XIX. század számos kiváló képességü szakembert adott a magyar gazdaságnak, de ezek közül is kimagaslott Edvi Illés Aladár, a kivételes tehetségü és intelligenciájú gépészmérnök. Az Óbudai Egyetem jogelődje, a Magyar Királyi Állami Felső Ipariskola tanára kiváló elméleti képességekkel és széles látókörrel rendelkezett. 1882-től 1920-ig felső ipariskolai tanári müködése mellett, mint iparfejlesztő is beírta nevét a történelembe.

Kulcsszavak: Magyar Királyi Állami Felsö Ipariskola, iparpolitikus, tanár, publicista

\section{Egy tevékeny pálya kezdete}

Edvi Illés Aladár 1858. január 6-án Kapuváron született, régi nemesi család sarjaként. Apja soproni ügyvéd, majd vármegyei ügyész volt. Középiskolai tanulmányait a soproni evangélikus gimnáziumban kezdte, majd - az 1873-as bécsi világkiállítás megtekintése után érdeklődése a gépészet felé irányulva - a soproni reáliskolában folytatta és fejezte be 1874-ben. Egyetemi tanulmányait a budapesti kir. József Müegyetemen kezdte, és az 1874/75. és az 1875/76. tanévet az egyetemes szakosztály hallgatójaként végezte el.

A második év befejezését követően a soproni 76. gyalogezrednél töltötte önkéntes katonai szolgálatát. Egyetemi tanulmányait az 1877/78. tanévben a müncheni müegyetem gépészmérnöki szakosztályának első évfolyamán kezdte újra. 1878 augusztusában behívót kapott, 1879. február végéig szolgált. Tanulmányait végül az aacheni müegyetemen folytatta az 1879/80. és az 
1880/1881. tanévben és gépészmérnöki oklevelét 1881. július 30-án vette át.

Hazatérve a Mechwart András vezette Ganz \& Társa budapesti gyárában kezdte meg mérnöki tevékenységét.[1]. 1882-ben a vallás- és közoktatásügyi miniszter a Budapesti Állami Ipartanodába ,,igazgató segédnek", 1884-ben rendkívüli, majd 1885-ben pedig rendes tanárrá nevezte ki a fémvasipari szaktárgyak oktatására.

Az 1896. évi ezredéves kiállításon a bányászati és kohászati, és a fém-vasipari csoportok bizottságának előadója volt, tapasztalatairól „Az 1896. évi ezredéves kiállítás eredményei" címü könyv VII. kötetében a számolt be [2]. Tevékenyen részt vett az 1900. évi párizsi világkiállítás fémvasipari csoportjának rendezésében, munkásságát a nemzetközi zsüri a kiállítás nagy aranyérmével tüntette ki [3].

A Budapesti Magyar Királyi Állami Felső Ipariskolában 1902-ig rendes tanárként oktatott, ekkor a kereskedelemügyi minisztériumba rendelték be központi szolgálattételre. A Felső Ipariskolától nem vált meg, 1920-ig, mint óraadó tanár tanított tovább. 1903. április 21-én felső ipariskolai igazgatói címet kapott. 1913-ban meghívták a Magyar Királyi József Müegyetem előadójának. Kezdetben „A Magyar-birodalom ipara" címmel tartott órákat, 1915-től a bányászati és iparpolitikai előadások megtartására kérték fel. A szakoktatás és az ipar terén kifejtett érdemei elismeréséül Öfelsége 1896-ban a koronás arany érdemkereszttel, 1901-ben a Ferenc József Rend lovagkeresztjével tüntette ki, 1916-ban pedig magyar királyi udvari tanácsossá nevezte ki.

1886-ban a Magyar Mérnök- és Építész Egylet (MMÉE) tagja lett, 33 éves korában az Egylet Közlönyének szerkesztőjévé választották [4]. Célja a Közlöny szerkesztésével az, hogy a folyóiratot oly magas fokra emelje, ahol a külföldi legjelesebb folyóiratok állnak. Ezzel a hazai kultúrának, a magyar és iparügynek, de különösen az Egyletnek kívánt hasznos szolgálatot, be- csületet és tiszteletet szerezni..." [5]. MMÉE Közlönyében rendszeresen jelentette meg szakmai ismeretterjesztő írásait. 1889 és 1924 között korának jelentős müszaki alkotásairól, a tudomány állásáról írt 36 összeállítása jelent meg, és 4 esetben közölték a közgyülésén mondott hozzászólását.

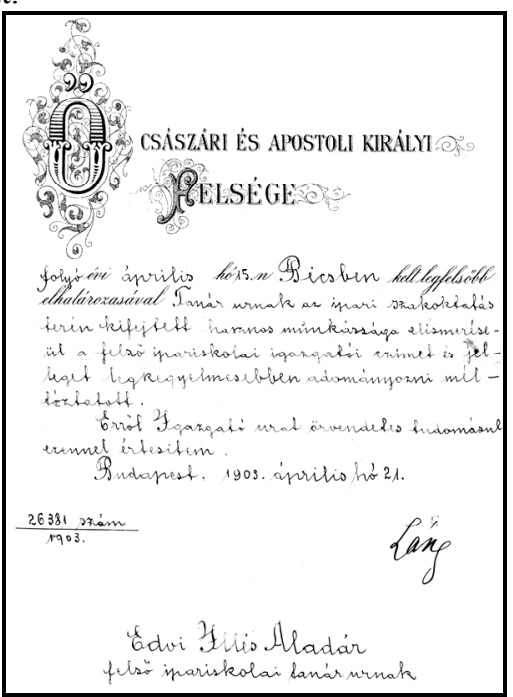

1. ábra. Felsö ipariskolai igazgatói cím adományozása (Láng Lajos Kereskedelmi m. kir. Miniszter)

A „Krómvas és a krómacél” címü tanulmányát a Mérnök Egylet 1891-ben Hollán-pályadíjjal jutalmazta.

A Közlönyben megjelent írásai közül is kiemelkednek a vas történetével, feldolgozásával, a vasgyártás helyzetével és statisztikai elemzésével foglalkozó cikkei. Így például „A vas története Közép- és ÉszakEurópában a népvándorlásig I-II-III. rész", „A folyasztott vas használata a kazángyártásban külföldön”, „Az elektrolízis munkája I-II-III rész”, „A vasöntés gyermekévei I-II rész”, „Délmagyarország első vasgyárai III-III rész”, „A világ vasipara 1898-ban és Magyarország vasfogyasztása", valamint a „Csonka-Magyarország vasgyártása ésszükséglete I-II rész". Széleskörü szakmai közéleti tevékenységet fejtett ki. Az Orszá- 
gos Gőzkazánvizsgáló Egyesület miniszteri biztosa volt. Tagja volt a MMÉE könyvkiadó bizottságának, az Országos Iparegyesületnek, a Természettudományi Társulatnak, az Országos Magyar Gazdasági Egyesületnek, az Országos Ipari és Kereskedelmi Oktatási Tanácsnak, a Statisztikai Hivatal Értékmegállapító Bizottságának, valamint a Magyar Szakírók Országos Egyesületének.
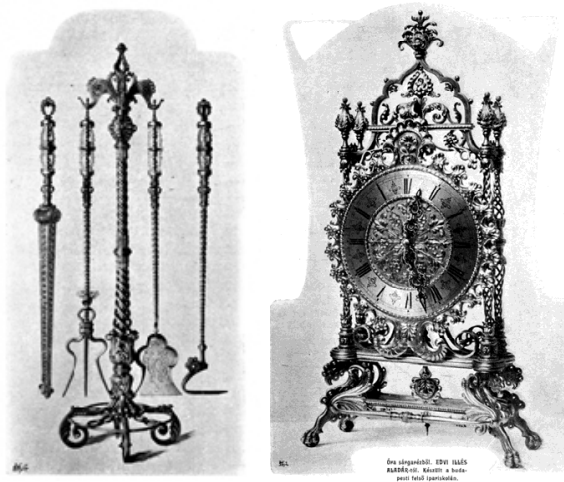

2. ábra. Edvi Illés Aladár alkotásai az 1900-as párizsi világkiállitáson

Tiszteletbeli tagja volt az Országos Gépészegyesületnek. Ellátta a „Vasárnapi Munkásképző Országos Bizottság” alelnöki feladatait is.

Edvi Illés Aladár 1898-tól számos tanulmányt készített a Magyar Királyi Kereskedelemügyi Minisztérium megbízásából. Egyik első jelentése a Székelyföld vasiparáról készült, mely elemzés is hozzájárult ahhoz, hogy a Kereskedelemügyi Minisztérium IX. szakosztályán a gyári és kisipari ügyek intézése, új iparágak megindítása és a meglevők fejlesztése lett fö feladata [5].

\section{Az iparpolitikus}

Az Iparegyesület 1867. szeptember 15re összehívott közgyülése által létrehozott bizottság a „magyar ipar újjáteremtésének munkálatát kezdeményezni" hivatott. A legfontosabbnak tartották ,,..a legifjabb iparnemzedék szellemi kiművelésére és szakmabeli kiképeztetésére..." létrehozni az iparegyleti iskolákat, az ipariskolai tankönyvek színvonalának emelését és az ipari szakirodalom terjesztését. Az egyesület kezdeményezésére az 1872-ben beterjesztett ipartörvény vitája során mindinkább „égető napirenddé” vált az Ipartanoda és az úgynevezett Technológiai Iparmúzeum létrehozási igénye. Hasonló jellegű intézményeket a fejlett ipari államok már a XIX. század elején alapítottak. A hazai Iparmúzeum létesítésének gondolatát Dr. Trefort Ágoston gróf Zichy Jenőhöz írt, a Pesti Naplóban közzétett levele mutatta be: ,...Ez okból indulva, tervet készíttetett, hogy az iparmúzeum $\mathrm{s}$ a rajztanárképezde oly iskolával hozassék kapcsolatba, hogy abban a nemesebb, vagyis a művészetekkel határos iparágak korszerủ gyakorlatához szükséges elméleti ismeretek taníttassanak, s a gyüjtemények tárgyainak használata mellett az iparosok gyakorlatilag oktassanak..." [6].

A Beleznay kerti épületben 1883. június 24-én 10 órakor az Iparmúzeumot Trefort Ágoston miniszter ünnepélyesen megnyitotta. Az alapszabály szerint: ,a hazai kézmüvesipart, elsősorban pedig a fa- és fémipart közhasznú szakismereteknek, lehetőleg szemléleti úton való terjesztésével támogatni, s a jelenkori igényekhez képest fejlődését hathatóan előmozdítani" volt az Iparmúzeum hivatása.

Trefort a múzeumot és az ipartanodát szerves kapcsolatba hozta. A Közép Ipartanoda igazgatóját, Hegedủs Károlyt bízta meg a múzeum vezetésével és főfelügyeletével föigazgatói minőségben. 1883-ban a miniszter Edvi Illés Aladárt kérte fel a múzeumban a vas- és fémipari elöadások tartására, melyet 17 éven át, 1900-ig folytatott. 1890-ben a Technológiai Iparmúzeumban szervezett kísérleti állomás fémipari müszaki szakértöjének nevezték ki.

Az 1890-es évek közepén a székely kivándorlás ellensúlyozására a magyar nagyvállalatoknál tanuló székely tanoncok gyámfelügyeletével bízták meg. Munkássága elismeréseként 1897-ben az ipari mun- 
kások részére szervezett országos bizottság alelnökévé választották. E bizottság keretében tevékenykedett a ,Vasárnapi munkásképzö bizottság", amely szaktanfolyamokkal, ismeretterjesztő előadásokkal és múzeumlátogatásokkal biztosította a gyáripari munkások továbbképzését. Egy évvel később a kereskedelemügyi miniszter az Országos Ipartörténeti Tanács tagjává nevezte ki.

1905-ben a m. kir. Kereskedelemügyi Minisztériumban megalakították az ipari müszaki osztályt, ennek vezetésével Edvi Illés Aladárt bízták meg. Új feladatai közé tartozott az ipartörvény felülvizsgálatával foglalkozó bizottság tagjaként az elöterjesztések összeállítása, valamint az Ausztriával kötendő gazdasági kiegyezés tárgyalásainak előkészítése.

Tagja volt a Magyar Királyi Közlekedési Múzeum Felügyelöbizottságának. 1914 elején a minisztérium megbízta a magyar müszaki múzeum létrehozásának előkészítésével. 1918-ban miniszteri megbízottként részt vett a vas- és vasötvözetek, illetve ócskavas bizottságok munkájában.

Edvi Illés Aladár széles látóköre kialakulásában meghatározó szerepe volt a számos értékes külföldi szakkönyvet is felsorakoztató - mintegy 30.000 kötetes könyvtárának. Első jelentősebb munkáját 1884-ben „Felsőmagyarország kisvasipara” címmel az Építési Ipar című lapban publikálta. 1889-ben, a Természettudományi Közlönyben jelent meg tanulmánya „Az alumínium jelene és jövője" címen, két évvel később már könyvet ír erröl az új fémröl [6]. 1891-ben jelent meg ,A vas technológiája" címü tankönyve. Ekkor kezdte szerkeszteni a MMÉE Közlönyét, melyben 1893-ban jelent meg „Délmagyarország első vasgyárai” címü ipartörténeti jelentöségü tanulmánya [7]. Szakírói munkásságával jelentősen hozzájárult a magyar müszaki nyelv kialakításához, a fogalomrendszer kialakításához.

A kereskedelemügyi miniszter megbízásából 1901-ben jelent meg ,A magyar ko- rona országainak gyáripara az 1898. évben" címü tanulmánya, 1906-ban a fa- és gépiparral is kibővített monográfiát készített. Mindkét munkája az Ausztriával folytatandó gazdasági kiegyezés előkészítéséhez készült. Edvi Illés Aladár 2010-ben a Pallas Nagy Lexikonának vas- és fémipari részének átdolgozását is elvállalta a Révai Testvérek Irodalmi Intézet Rt. megbízásából.

Edvi Illés Aladárt 1908-ban miniszteri osztálytanácsossá nevezték ki. 1919-től a Kereskedelemügyi Minisztérium gazdasági szakosztályának vezetője volt, 1922-ben, 64 éves korában helyettes államtitkárként ment nyugállományba. Munkássága elismeréseként a MMÉE 1924-ben tiszteletbeli tagjává választotta, majd az Egylet közgazdasági osztályának megalakulásától elnöki tisztét is betöltötte.

1927 januárjában súlyos betegség döntötte ágynak, de akaratereje és a gondos ápolás talpra állította. A betegség azonban újra támadta szervezetét, amit már nem volt képes leküzdeni: 1927. április 24-én hunyt el a széles látókörrel, kiváló szervezőképességgel és tudással rendelkező mérnök, felső ipariskolai tanár, iparpolitikus, szakíró.

\section{Szakirodalmi hivatkozások}

[1] Bencze G.: Váci út, a magyar gyáripar föutcája. Budapest: Országos Pedagógiai Könyvtár és Múzeum, 2006.

[2] Edvi I. A.: Az 1896. évi ezredéves kiállitás eredményei, VII. kötet. Vas- és fémipar, Budapest, 1898, 241-326. oldal

[3] Jesch L.: A Budapesti Magyar Királyi Állami Felsö Ipariskola emlékkönyve, Budapest, 1939.

[4] Magyar Mérnök-és Építészegylet Közlönye, 1917. (LI. kötet), 112-114. oldal

[5] Terplán Z., Németh G.: A Magyar Mérnökés Épitész-egylet Közlönyének adatai 18671944 között, Miskolci Egyetem, 1998

[6] Gáti J.: Ipartanodától egyetemig, Óbudai Egyetem Kiadó, Budapest, 2010. 110. o.

[7] Magyar Mérnök-és Épitész Egylet Közlönye, 19-20. szám, 1927. május 22. 105.o. 